\title{
STABILITY STUDY OF OPEN MINE SLOPES AT PIT 22 GN PT KITADIN SITE EMBALUT, KUTAI KARTANEGARA REGENCY, EAST KALIMANTAN PROVINCE
}

\author{
KAJIAN KESTABILAN LERENG TAMBANG TERBUKA PADA PIT \\ 22 GN PT KITADIN SITE EMBALUT, KABUPATEN KUTAI \\ KARTANEGARA, PROVINSI KALIMANTAN TIMUR
}

\author{
TANDIDATU T. DENY and SUNDEK HARIYADI ${ }^{*}$ \\ Mining Engineering Program, Faculty of Mining Engineering, \\ Kutai Kartanegara University, Tenggarong, East Kalimantan. \\ *Corresponding e-mail: sundecktambang@gmail.com
}

\begin{abstract}
The stability of slope, both on the slope of work and the final slope, is a very important aspect of slope stability, both on the slope of work and the final slope in open pit mining activities. The inconsistency of the slopes will result in the collapse of rocks around the excavation site. This happens because the condition of the rock when it has not been excavated is generally balanced. However, due to the discontinuous patterns that occur other than naturally and also due to the mining activities such as excavation, blasting and others, cause a reduction in the retaining force of the rock on the slope results in the equilibrium of the force tends to shift and is not balanced. Study of the stability of the open pit highwall slope at PIT 22 GN PT Kitadin Site Embalut, Kutai Kartanegara Regency, East Kalimantan Province was carried out with the aim to know the rock characteristics, to calculate slope geometry stable safety factors, and to recognize the type of landslide using a bishop method. The results of the modeling consist of several heights and slopes, as well as angles that is formed. Section AA' has a safety factor value of 1.387 , section BB has a safety factor of 1.482 , section BB' has a safety factor value of 1.390 , section DD' has a safety factor value of 1.318 , section $E E$ has a safety factor value of 2,381 , section FF' has a safety factor value of 2.426 , section GG' has a safety factor value of 2.424 , section $\mathrm{HH}$ 'has a safety factor value of 2.339 .
\end{abstract}

Keywords: highwall slope stability, open mine, pit 22 GN, coal.

\begin{abstract}
ABSTRAK
Kestabilan lereng, baik pada lereng kerja maupun lereng akhir merupakan aspek kemiringan yang sangat penting, baik pada kemiringan pekerjaan dan kemiringan akhir merupakan aspek yang sangat penting dalam tambang terbuka. Ketidakkonsistenan lereng akan mengakibatkan runtuhnya batu di sekitar lokasi penggalian. Ini terjadi karena kondisi ketika belum digali umumnya seimbang. namun, akibat pola-pola diskontinu yang terjadi secara alamiah dan juga disebabkan oleh aktivitas penambangan seperti penggalian, peledakan dan sebagainya, menyebabkan berkurangnya gaya penahan terhadap batuan pada lereng itu sehingga kesetimbangan gaya yang selama ini terjadi cenderung bergeser dan tidak seimbang. Kajian kestabilan lereng highwall tambang terbuka pada PIT 22 GN PT Kitadin Site Embalut Kabupaten Kutai Kartanegara Provinsi Kalimantan Timur dilakukan dengan tujuan untuk mengetahui karakteristik batuan, menghitung geometri lereng, menghitung faktor keamanan yang stabil, dan mengetahui tipe longsoran menggunakan metode bishop. Hasil pemodelan terdiri dari beberapa ketinggian dan kemiringan, serta sudut yang membentuk. Penampang $A A^{\prime}$ memiliki nilai faktor keamanan 1.387, penampang $B B$ memiliki faktor keamanan 1,482, penampang BB' memiliki nilai faktor keamanan 1,390, penampang $D D^{\prime}$ memiliki nilai faktor keamanan 1.318, penampang EE memiliki nilai faktor keamanan 2.381, penampang FF' memiliki nilai faktor keamanan 2.426, penampang GG' memiliki nilai faktor keamanan 2.424, dan penampang HH' memiliki nilai faktor keamanan sebesar 2.339.
\end{abstract}

Kata kunci: kestabilan lereng highwall, tambang terbuka, pit 22 GN, batubara 


\section{INTRODUCTION}

The stability of slope, both on the slope of work and the final slope is a very important aspect in open pit mining activities. The inconsistency of a slope will result in the collapse of rocks around the excavation site. This happens because the condition of the rock when it has not been excavated is generally in equilibrium. However, due to the discontinuous patterns that occur other than naturally and also due to the mining activities such as excavation, blasting and so on, cause a reduction in the retaining force of the rock on the slope so that the equilibrium of the force that has occurred tends to shift and not balanced (Hoek and Brown, 1980).

PT Kitadin - Embalut is a company engaged in the coal mining industry located in the village of Embalut, Tenggarong Seberang Sub district, Kutai Kartanegara Regency, East Kalimantan Province, a subsidiary of BANPU owned by foreign capital owners (THAILAND). PT Kitadin - Embalut established in 1978 in the exploration stage, while the production started in 1983 with mining authority Exploration KW. 96P / 00174 / Kaltim and with an area of 2,973.6 Ha (since March 2000). In this area, 12 coal seams have been found with diffuse, thick and varied qualities.

Study of the stability of the open pit highwall slope at PIT 22 GN PT Kitadin Site Embalut, Kutai Kartanegara Regency, East Kalimantan Province was carried out with the aim of knowing rock characteristics, calculating slope geometry, calculating stable safety factors, and knowing the type of landslide (Figure 1).

\section{METHODS}

\section{Stages of Preparation}

Literary studies are literature journals, scientific journals, literature books supporting research, internet websites, so it is expected that with strong theoretical conclusions scientific research will be obtained.

\section{Stages of Field Observation}

The survey aims to find primary and secondary data related to the planning, modeling and the final situation of a design Pit 22 GN PT. Kitadin.

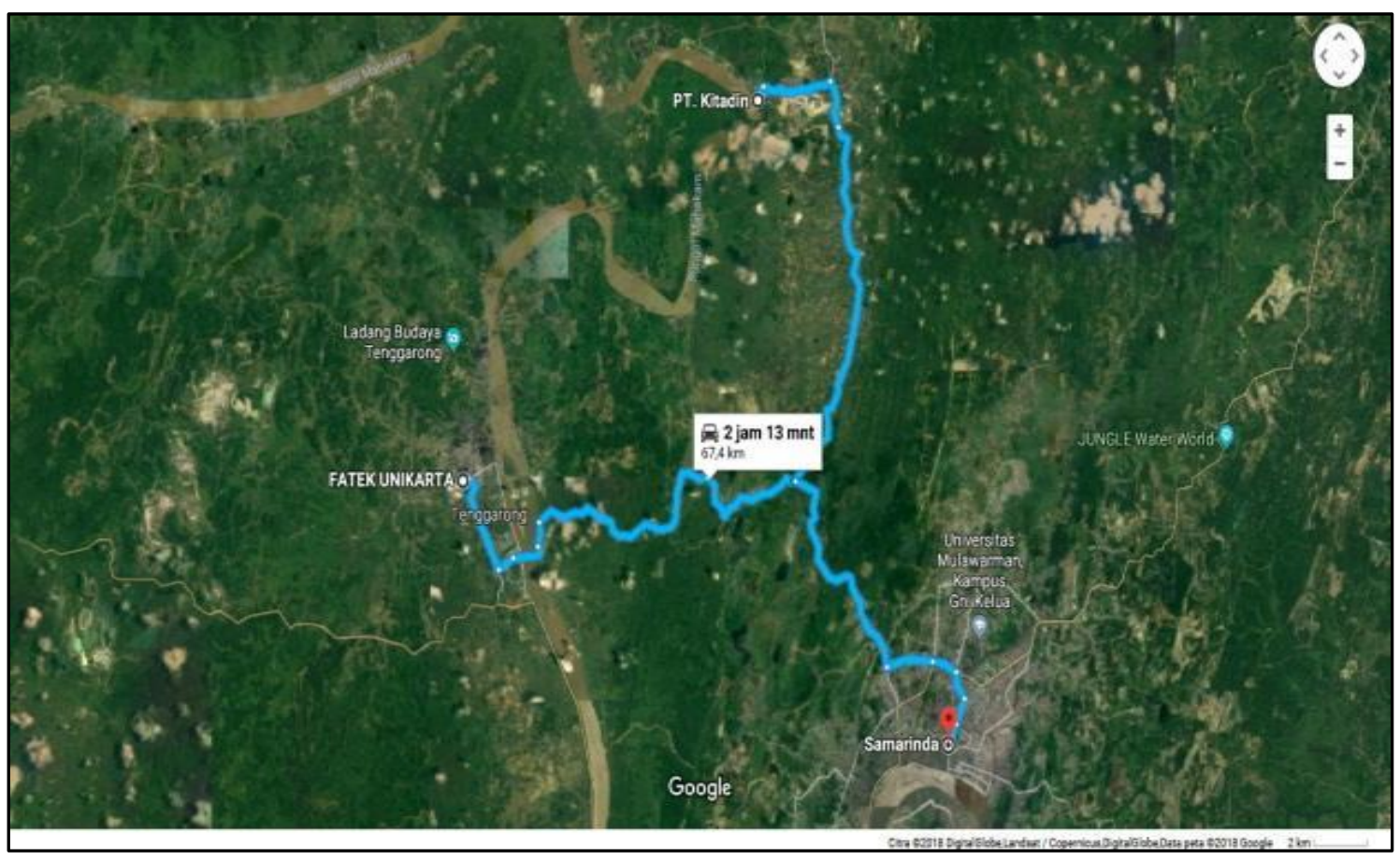

Figure 1. The research area is located in Embalut Village, Tenggarong Seberang Sub district, Kutai Kartanegara Regency, East Kalimantan 


\section{Data Collection}

Primary data aims to collect large amounts of data obtained directly by the researchers in the form of rock characteristic data, lithology description, ground water level, and documentation. The secondary data retrieval process is to collect the results of previous studies or studies for example from reports of technical geological analysis (geotech), feasibility study reports, planning maps and mine situation maps, especially on the highwall slopes that will be examined. In addition, the results of the shear strength test laboratory data were carried out.

\section{Data Processing Stages}

Data that has been collected is then processed with the help of software, among others: Microsoft Office Excel and Microsoft Office Word, Autocad, Slide, and Minescape.

\section{Study of Research Data}

The stages of study of the data from this research are the final stages of data processing. The data that has been captured in a recapitalization data study is conducted to:

1. Data processing aided by the software: Microsoft and Microsoft Office.

2. The assessment of the technical geological test results data is accomplished by AutoCAD and Slide version 6.00 softwares.

\section{BASIC THEORY}

\section{Slope Stability}

Sediment excavated mining activity are often preceded by stripping the overburden to obtain the desired material. The lower the position of the material being excavated, the more coverings that must be removed. As a result, removing the overburden will cause differences in the height of the work area (front) of the surrounding rock layers. Because of the difference in height between the two surfaces which will later make an inclined plane or upright plane connecting the two surfaces, which are often called slopes.
Slopes can be formed naturally and can also be made by humans. According to Budiman (2011), there are three types of slopes, namely:

1. Natural slopes, namely slopes formed by natural processes, such as hillsides.

2. Slopes are made with native land, for example if land is cut down to make roads or waterways for irrigation purposes.

3. Slopes made of compacted soil, as dikes for roads or dams.

Failure can be divided into four types, namely plane, wedge, toppling, and circular failures (Karyono, 2004). Factors that cause landslide prone slopes include internal and external factors such as earthquakes, climates, vegetations, morphologies, rocks, soil moisture levels, seepages, and geological activities such as fractures, fractures and lines (Zakaria, 2010).

Slope stability conditions in the limit equilibrium method are expressed in the safety factor index (FK). The safety factor is calculated using force equilibrium or moment equilibrium, or using the two equilibrium conditions depending on the calculation method used (Azizi and Handayani, 2011).

In general, a slope can be said to be stable if the safety factor is greater than one. Slope stability depends on the shear strength of the soil. The displacement of the soil is due to the relative movement of the soil grains. Therefore, the shear strength of the soil depends on the forces acting between the grains. Soil in a grain arrangement such as the distribution of grain size and the amount of contact between grains, the shear strength is greater than the loose soil (Das, Endah and Mochtar, 1993).

\section{Bishop Method}

The simplified wedge method used in the Bishop method (Bishop, 1955). This method assumes that the force acting on the side of the slice has zero generated in the vertical direction. The equation of shear strength in the review of the effective stress that can be used by the soil, until the achievement of the boundary balance condition by observing the safe factor (Figure 2). 


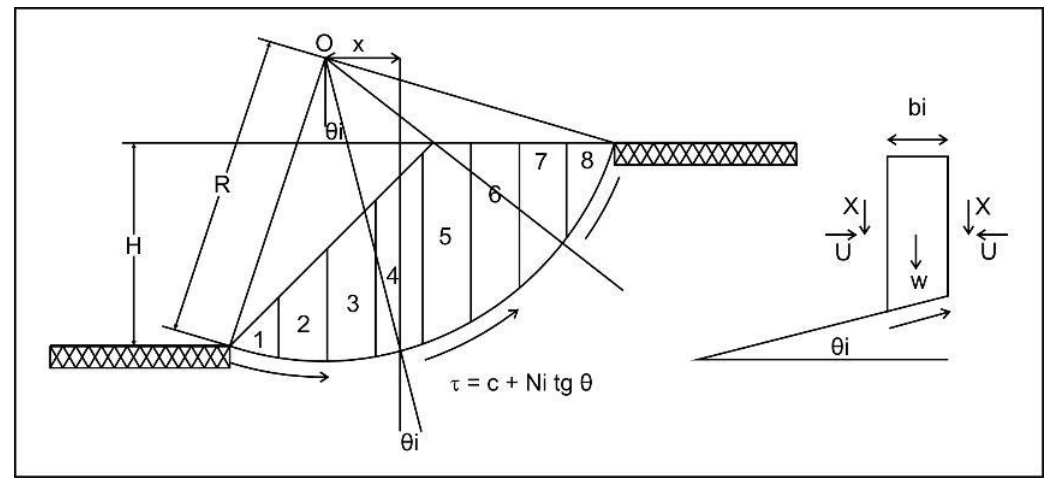

Figure 2. Style that work on a slice (Hardiyatmo, 2017)

Another form of the safe factor equation for slope stability analysis with the Bishop method is:

$$
\begin{aligned}
& \mathrm{F}=\frac{\sum_{i=1}^{\mathrm{i}=n} \mathrm{c}^{\prime} \mathrm{b}_{\mathrm{i}}+\mathrm{W}_{\mathrm{i}}\left(1-\mathrm{r}_{\mathrm{u}}\right) \tan \tan \theta^{\prime}\left(\frac{1}{\cos \theta_{\mathrm{i}}\left(1+\tan \tan \theta_{\mathrm{i}} \tan \theta^{\prime} / \mathrm{F}\right.}\right)}{\sum_{i=1}^{\mathrm{i}=1} \mathrm{~W}_{1} \sin \sin \theta_{\mathrm{i}}} \\
& \mathrm{F} \quad=\text { safety factor } \\
& \mathrm{C}^{\prime} \quad=\text { effective soil cohesion } \\
& \varnothing^{\prime} \quad=\text { effective friction angle in the soil } \\
& \mathrm{bi} \quad=\text { width of the slice to }-\mathrm{i} \\
& \mathrm{Wi} \quad=\text { width of slice to ground }-\mathrm{i} \\
& \varnothing_{\mathrm{i}} \quad=\text { the angle defined } \\
& \mathrm{ui} \quad=\text { water pressure on iris to }-\mathrm{i}
\end{aligned}
$$

\section{RESULTS AND DISCUSSION}

\section{Results}

The final mining phase of Pit 22 is currently at Seam 23 which has reached the lowest depth $(-10) \mathrm{m}$ and for the final mining stage is at Seam 22 reaching the lowest depth $(-40) \mathrm{m}$, as the mining deadline for 2018 production year. Slope stability analysis in this area was carried out in order to determine the level of slope stability indicated by a number of safety factors, so prevention can be done to avoid the danger of avalanches.

In calculating slope stability, the soil strength parameter data obtained from laboratory testing of rock samples were carried out at the Geotech Laboratory, PT Kitadin Site Embalut. The type of test and the number of laboratory tests performed for slope stability analysis is the Geotechnical test which aims to determine the physical and mechanical properties of rocks in the overburden, which includes fill weight, cohesion and inner shear angle. where the results are needed to determine the height and angle of the slope in stable conditions both for mining operations and cover landfilling operations.

The calculation carried out looks at the condition of the study area at this time and is differentiated based on the slope constituent material, the slope model and the slope state can be displayed using the Slide 6.0 version of the bishop method.

\section{Slope Stability Analysis}

After processing the data on several samples from drilling, the material data from all lithology are grouped into the coal cover zone. These data will be entered into the software as rock parameters along with a cross section design which will be used as external boundary and boundary material.

The cross-sectional design of the slope was first reconstructed with the help of 4.119, and AutoCAD 2016. Minescape software. Slope reconstruction results were then imported into slide 6.0 software and weighted the rock properties of each interburden layer. The final results of the process of determining the value of safety factors are as follows:

\section{Analysis of Single Slope Stability}

Single slope stability analysis was calculated using the Simplified Bishop Method. There are several calculations that are set as approaches, namely:

a. Single slope constituent material is assumed to be homogeneous;

b. The minimum slope safety factor used for analysis is $\mathrm{FK} \geq 1.2$ (Hariyadi, 2014);

c. The condition of the material being analyzed that is considered saturated. 
1. Single slope material characteristic The characteristics of a single slope material used for the analysis of single slope stability using the slide 6.0 program are cohesion $(C)$, inner $(\theta)$ shear angle, and rock specific gravity (Table 1.)

2. Single slope modeling

Single slope modeling is carried out to obtain the safety factor (FK) of all materials that are part of the overall slope. Calculations are carried out for several variations of height, namely 1 meter - 40 meters with several variations of slope namely $20^{\circ}-70^{\circ}$ (Figure 3) and (Table 2).

\section{Analysis of Overall Slope Stability}

The overall slope stability analysis aims to determine the highwall slope safety factor based on slope cross section data with several variations in altitude and slope. The analysis was carried out using the bishop method with the help of the slide 6.0 program.
In this analysis, several approaches were carried out, namely:

a. The rock coating condition was approached by following coal coating as illustrated in the cross section;

b. The analyzed slopes are considered not to be disturbed by external factors which can affect the strength of the rock mass;

c. The slope condition that will be analyzed has a groundwater level;

d. The minimum safety factor used for analysis is 1.2 .

1. Overall slope material characteristic.

The overall slope material characteristics are the result of analysis in the geotech laboratory which includes the results of physical and mechanical tests of rocks (Table 3).

2. Overall slope modeling

The final results of the process of determining the value of safety factors are as follows: (Table 4 and Figure 3 )

Table 1. Characteristics of single slope material

\begin{tabular}{|c|c|c|c|c|c|}
\hline \multirow[b]{2}{*}{ Pit } & \multirow[b]{2}{*}{$\begin{array}{l}\text { Material Grouping } \\
\text { Zone }\end{array}$} & \multirow[b]{2}{*}{ Prefix } & \multirow[b]{2}{*}{$\begin{array}{l}\text { Unit Weight } \\
\qquad \mathrm{KN} / \mathrm{m}^{3}\end{array}$} & \multicolumn{2}{|c|}{ Shear Strength Parameter } \\
\hline & & & & $\begin{array}{c}\text { Cohesion-Peak } \\
\left(\mathrm{KN} / \mathrm{m}^{2}\right)\end{array}$ & $\begin{array}{c}\text { Friction Angle Peak } \\
\text { (deg) }\end{array}$ \\
\hline \multirow{4}{*}{ S22GN } & Soil Material & SO & 17.01 & 80.47 & 21.09 \\
\hline & Disposal Material & $\mathrm{DI}$ & 18.14 & 4.00 & 10.00 \\
\hline & Overburden & OB & 21.42 & 132.39 & 31.76 \\
\hline & Interburden 23 C 22 & IB 23 C 22 & 20.88 & 144.07 & 31.04 \\
\hline
\end{tabular}

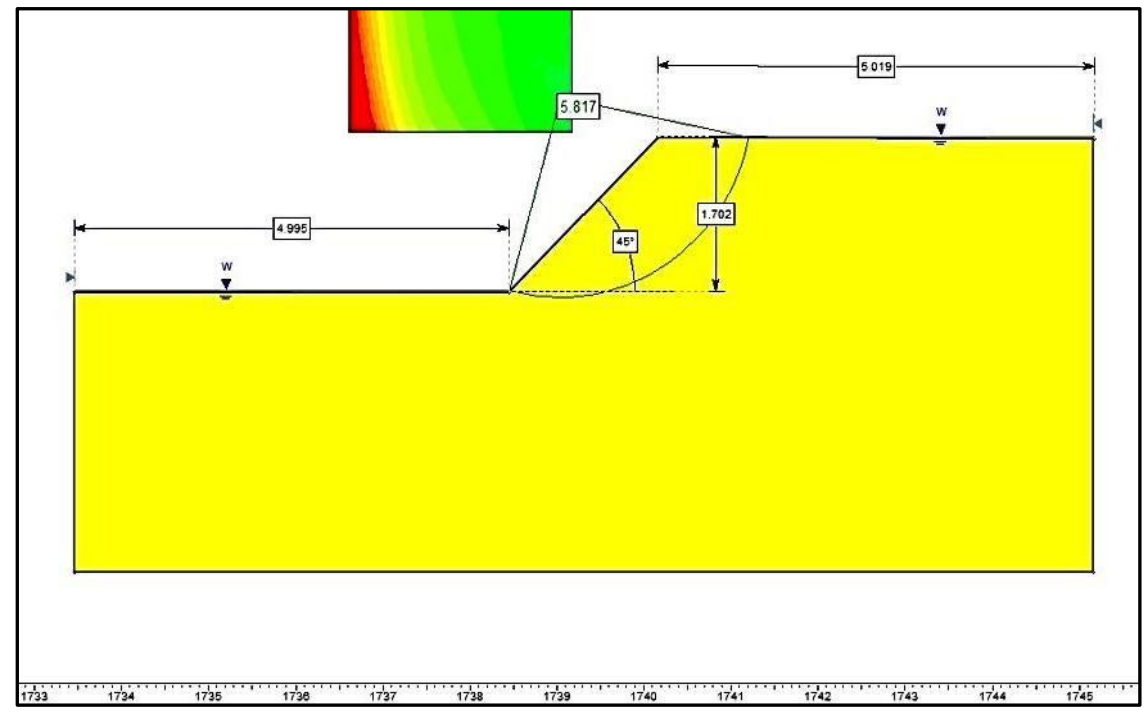

Figure 3. Single slope modeling results on sandstone 
Table 2. The result of single slope analysis

\begin{tabular}{|c|c|c|c|c|c|c|c|c|c|c|c|}
\hline \multicolumn{3}{|c|}{ OB } & \multicolumn{3}{|c|}{ IB 23 с 22} & \multicolumn{3}{|c|}{ Disposal } & \multicolumn{3}{|c|}{ Soil } \\
\hline High & Corner & FK & High & Corner & FK & High & Corner & FK & High & Corner & FK \\
\hline$(\mathrm{m})$ & $\circ$ & & $(\mathrm{m})$ & $\circ$ & & $(\mathrm{m})$ & $\circ$ & & $(\mathrm{m})$ & $\circ$ & \\
\hline \multirow{9}{*}{5} & 20 & 11.264 & \multirow{5}{*}{10} & 50 & 4.4 & \multirow{9}{*}{1} & 20 & 1.837 & \multirow{2}{*}{1.7} & \multirow{2}{*}{$\begin{array}{l}45 \\
60 \\
\end{array}$} & \multirow{2}{*}{$\begin{array}{l}5.817 \\
5.104\end{array}$} \\
\hline & 25 & 9.21 & & 55 & 4.18 & & 25 & 1.721 & & & \\
\hline & 30 & 8.837 & & 60 & 4.154 & & 30 & 1.646 & & & \\
\hline & 35 & 8.464 & & 65 & 3.829 & & 35 & 1.582 & & & \\
\hline & 40 & 8.091 & & 70 & 3.639 & & 40 & 1.494 & & & \\
\hline & 45 & 7.927 & \multirow{5}{*}{12} & 50 & 3.448 & & 45 & 1.43 & & & \\
\hline & 50 & 7.507 & & 55 & 3.258 & & 50 & 1.33 & & & \\
\hline & 55 & 7.087 & & 60 & 3.068 & & 55 & 1.293 & & & \\
\hline & 60 & 6.854 & & 65 & 2.877 & & 60 & 1.212 & & & \\
\hline \multirow{8}{*}{10} & 20 & 9.994 & & 70 & 2.687 & \multirow{3}{*}{2} & 20 & 1.105 & & & \\
\hline & 25 & 5.425 & \multirow{5}{*}{15} & 50 & 2.497 & & 25 & 1.007 & & & \\
\hline & 30 & 5.091 & & 55 & 2.306 & & 30 & 0.941 & & & \\
\hline & 40 & 4.455 & & 60 & 2.116 & & & & & & \\
\hline & 45 & 4.214 & & 65 & 1.926 & & & & & & \\
\hline & 50 & 3.9133 & & 70 & 1.735 & & & & & & \\
\hline & 55 & 3.973 & & 50 & 1.545 & & & & & & \\
\hline & 60 & 3.862 & & 55 & 1.355 & & & & & & \\
\hline & 40 & 3.243 & 17 & 60 & 1.164 & & & & & & \\
\hline 15 & 50 & 2.753 & & 65 & 0.974 & & & & & & \\
\hline & 60 & 2.597 & & 70 & 0.784 & & & & & & \\
\hline 17 & 60 & 2.386 & & & & & & & & & \\
\hline
\end{tabular}

Source: The research result

Table 3. Overall slope characteristics

\begin{tabular}{|c|c|c|c|c|c|}
\hline \multirow[b]{2}{*}{ Pit } & \multirow[b]{2}{*}{ Material Grouping Zone } & \multirow[b]{2}{*}{ Prefix } & \multirow{2}{*}{$\begin{array}{c}\text { Unit } \\
\text { Weight } \\
\mathrm{KN} / \mathrm{m}^{3}\end{array}$} & \multicolumn{2}{|c|}{ Shear Strength Parameter } \\
\hline & & & & $\begin{array}{c}\text { Cohesion Peak } \\
\left(\mathrm{KN} / \mathrm{m}^{2}\right)\end{array}$ & $\begin{array}{c}\text { Friction Angle Peak } \\
\left({ }^{\circ}\right)\end{array}$ \\
\hline \multirow{9}{*}{ S22GN } & Soil Material & $\mathrm{SO}$ & 17.01 & 80.47 & 21.09 \\
\hline & Soft Material & SF & 14.71 & 2.00 & 8.90 \\
\hline & Disposal Material & DI & 18.14 & 4.00 & 10.00 \\
\hline & Overburden & $\mathrm{OB}$ & 21.42 & 132.39 & 31.76 \\
\hline & Coal Seam 23 & C 23 & 14.57 & 138.56 & 38.94 \\
\hline & Interburden 23 C 22 & IB 23 C 22 & 20.88 & 144.07 & 31.04 \\
\hline & Coal Seam 22 & C 22 & 14.57 & 138.56 & 35.94 \\
\hline & Interburden 22 C 20 & IB 22 C 20 & 21.48 & 162.26 & 32.45 \\
\hline & Coal Seam 20 & C 20 & 17.27 & 115.33 & 36.78 \\
\hline \multirow{5}{*}{ S22GN } & Coal Seam 20 & C 20 & 17.27 & 115.33 & 36.78 \\
\hline & Interburden 20 C 17 & IB 20 C 17 & 21.52 & 259.66 & 34.6 \\
\hline & Coal Seam 17 & C 17 & 13.24 & 150 & 40 \\
\hline & Interburden 17 C 15UUU & IB 17 C 15UUU & 22.26 & 458.64 & 35.09 \\
\hline & Underburden & UB & 21.59 & 329.99 & 44.57 \\
\hline
\end{tabular}

Sources: Geotechnical Laboratory PT Kitadin Site Embalut

Table 4. Overall slope modeling results

\begin{tabular}{cccccccccccc}
\hline $\begin{array}{c}\text { High } \\
\mathrm{m}\end{array}$ & $\begin{array}{c}\text { Corner } \\
\circ\end{array}$ & FK & $\begin{array}{c}\text { High } \\
\mathrm{m}\end{array}$ & $\begin{array}{c}\text { Corner } \\
\circ\end{array}$ & FK & $\begin{array}{c}\text { High } \\
\mathrm{m}\end{array}$ & $\begin{array}{c}\text { Corner } \\
\circ\end{array}$ & FK & $\begin{array}{c}\text { High } \\
\mathrm{m}\end{array}$ & $\begin{array}{c}\text { Corner } \\
\circ\end{array}$ & FK \\
\hline 49.581 & 31 & 1.64 & 58.267 & 31 & 1.502 & 60.234 & 29 & 1.667 & 42.796 & 36 & 1.318 \\
49.581 & 33 & 1.531 & 58.267 & 32 & 1.482 & 59.934 & 31 & 1.39 & 44.229 & 37 & 1.201 \\
49.581 & 35 & 1.387 & 58.267 & 36 & 1.32 & & & & & & \\
\hline
\end{tabular}


Stability Study of Open Mine Slopes at Pit 22 GN PT Kitadin ... Tandidatu T. Deny and Sundek Hariyadi

\begin{tabular}{cccccccccccc}
\hline \multicolumn{3}{c}{ SEC E-E' } & \multicolumn{3}{c}{ SEC F-F' } & \multicolumn{3}{c}{ SEC G-G' } & \multicolumn{3}{c}{ SEC H-H' } \\
\hline $\begin{array}{c}\text { High } \\
\text { m }\end{array}$ & $\begin{array}{c}\text { Corner } \\
{ }^{\circ}\end{array}$ & FK & $\begin{array}{c}\text { High } \\
\mathrm{m}\end{array}$ & $\begin{array}{c}\text { Corner } \\
{ }^{\circ}\end{array}$ & FK & $\begin{array}{c}\text { High } \\
\mathrm{m}\end{array}$ & $\begin{array}{c}\text { Corner } \\
{ }^{\prime}\end{array}$ & FK & $\begin{array}{c}\text { High } \\
\mathrm{m}\end{array}$ & $\begin{array}{c}\text { Corner } \\
\circ\end{array}$ & FK \\
\hline 45 & 17 & 3.739 & 29.112 & 25 & 2.707 & 28.954 & 27 & 2.559 & 28.266 & 30 & 2.396 \\
41.45 & 23 & 2.769 & 29 & 29 & 2.426 & 28.954 & 31 & 2.242 & 28.358 & 27 & 2.567 \\
40.52 & 25 & 2.381 & & & & & & & & & \\
\hline
\end{tabular}

Source: The research result

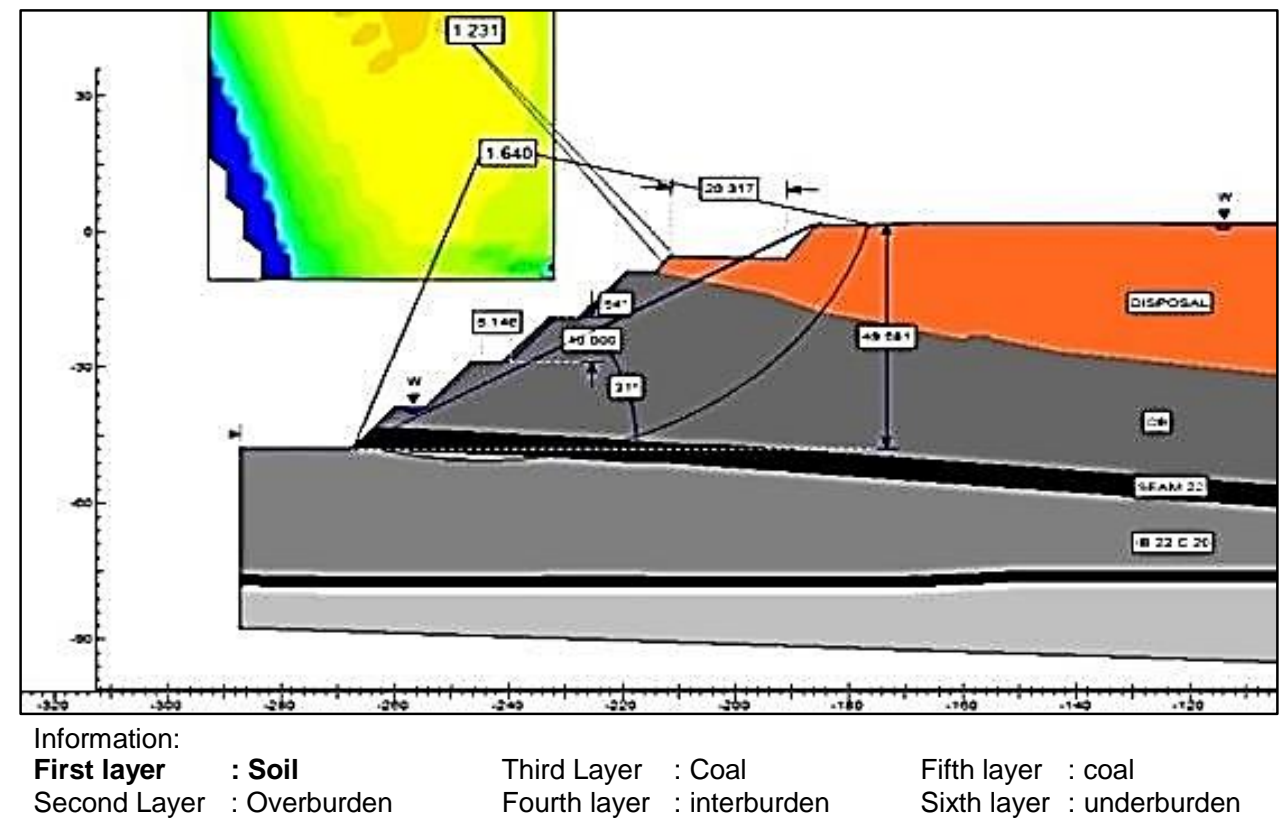

Figure 3.a. Overall slope modeling results with a slope height of 49.5 meters, angle $31^{\circ}$

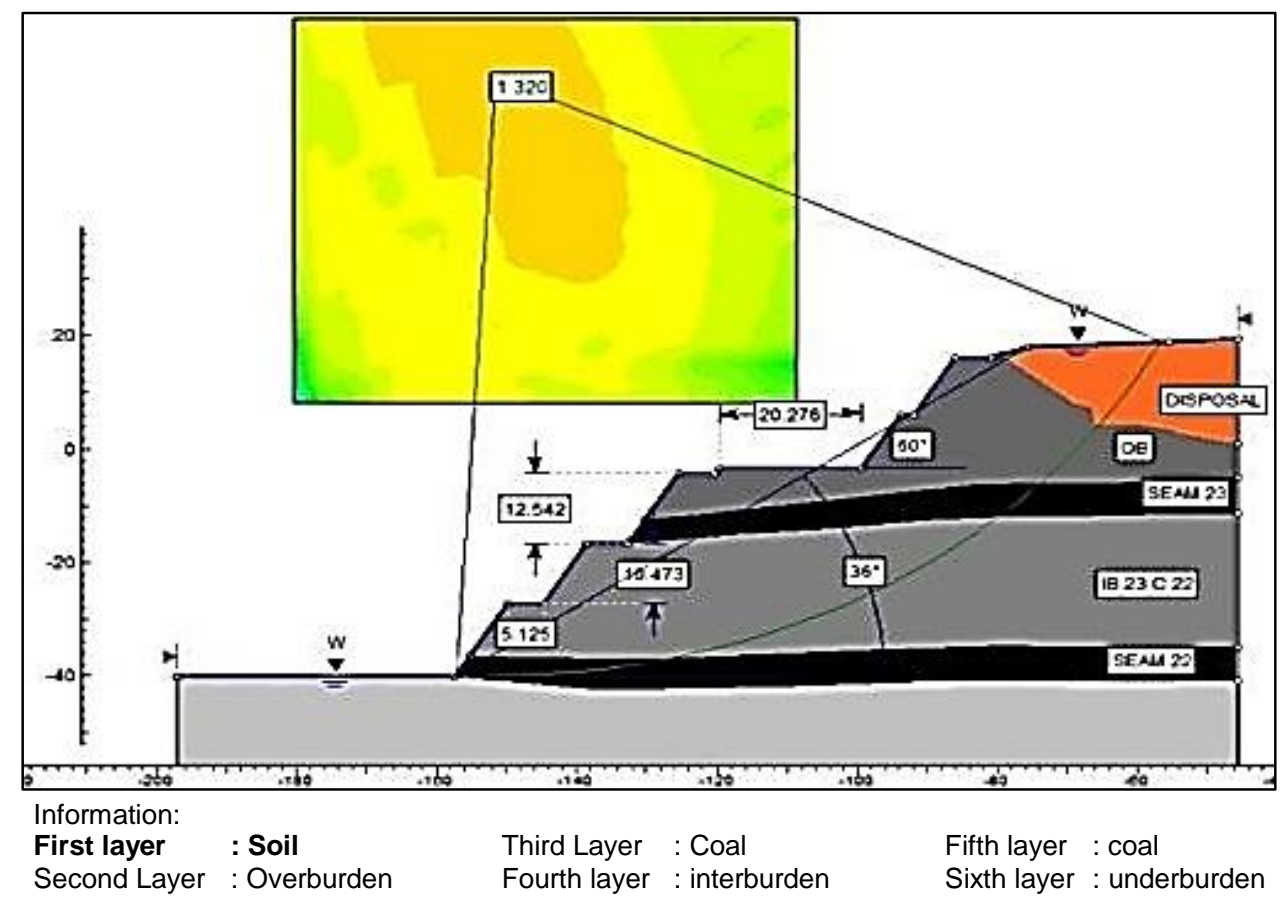

Figure 3.b. Overall slope modeling results with a slope height of 58.26 meters, angle $36^{\circ}$ 


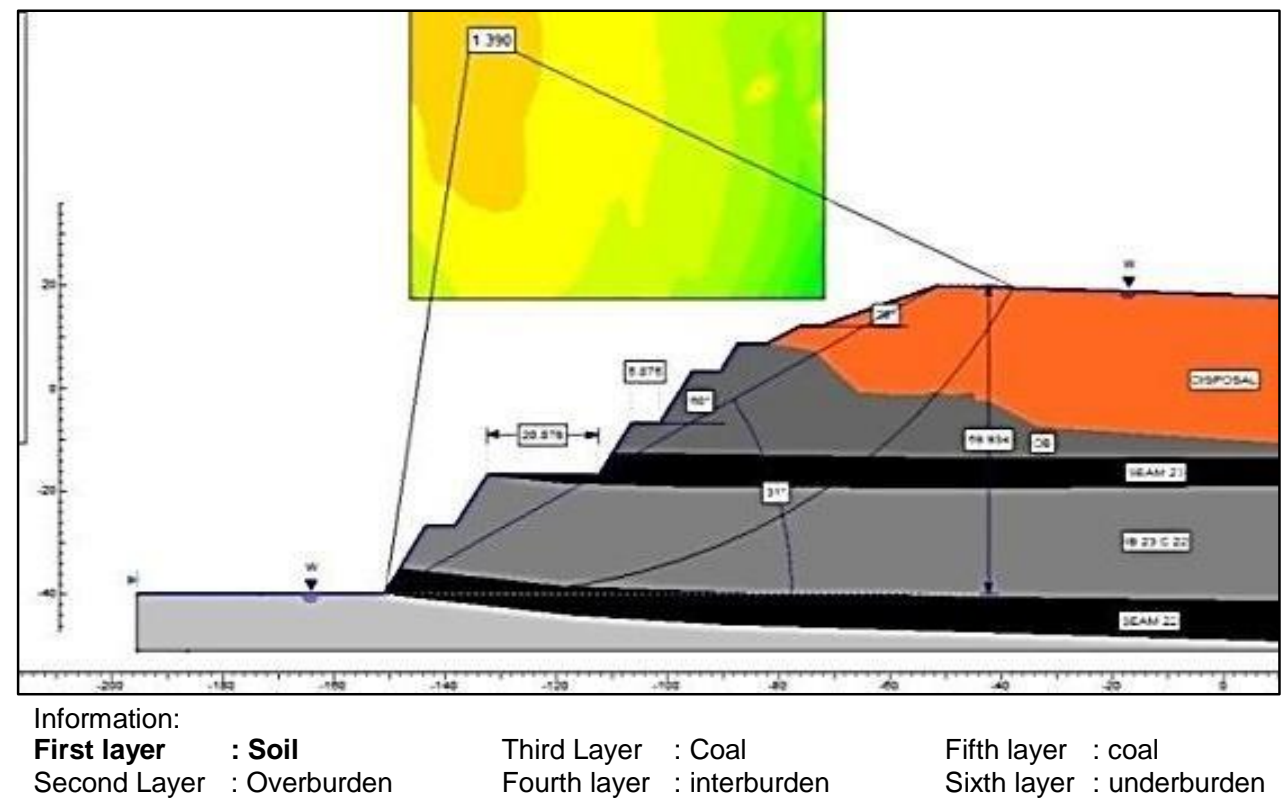

Figure 3.c. Overall slope modeling results with a slope height of 59.9 meters, angle $31^{\circ}$

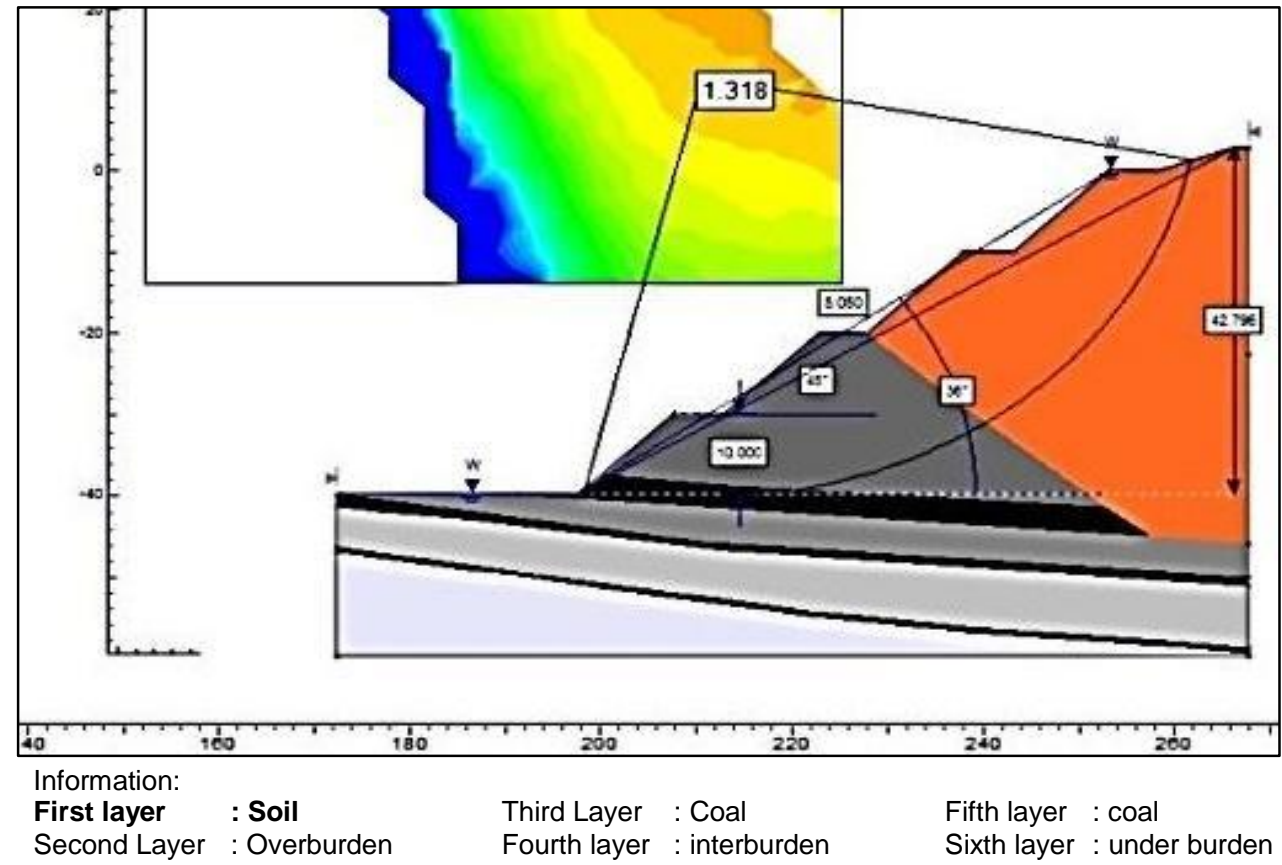

Figure 3.d. Overall slope modeling results with a slope height of 42.79 meters, angle $36^{\circ}$

\section{Discussion}

\section{Result of Analysis of Slope Stability}

The results of slope analysis using software slide version 6 will be obtained by the safety factor (FK). Slope stability analysis is divided into eight sections, the first is section A-A' with (berm $5 \mathrm{~m}$, overall height $49.851 \mathrm{~m}$, overall slope 350 ) produces a value of safety factor 1.387, section B-B' with (berm $5 \mathrm{~m}$, height level $58.276 \mathrm{~m}$, the overall slope 320 ) produces a safety factor of 1.482 , section B$\mathrm{B}^{\prime}$ with (berm $5 \mathrm{~m}$, overall height of $60.913 \mathrm{~m}$, overall slope 340) produces a safety factor value of 1.390, section D-D' with (berm $10 \mathrm{~m}$, height the overall level is $42.769 \mathrm{~m}$, overall slope 360 ) produces a safety factor value of 
1,318, section E-E' with (berm $5 \mathrm{~m}$, overall level of $40.515 \mathrm{~m}$, overall slope 250) produces a value of safety factor 2.381 , section $\mathrm{F}^{-\mathrm{F}^{\prime}}$ overall height of $29.112 \mathrm{~m}$, overall slope 200 ) produces a value of safety factor 2.426, section G-G' with (berm $10 \mathrm{~m}$ overall height $28.954 \mathrm{~m}$, overall slope 310 ) produces a value of safety factor 2.424 , section $\mathrm{H}-\mathrm{H}^{\prime}$ with (berm $10 \mathrm{~m}$, overall height $28.266 \mathrm{~m}$, overall slope 300 ) results in a safety factor value of 2.339 .

\section{Causes of Slope Instability}

1. Slope geometry

The higher the slope value of the safety factor in a mine slope the smaller or insecure the slope (Figure 4).

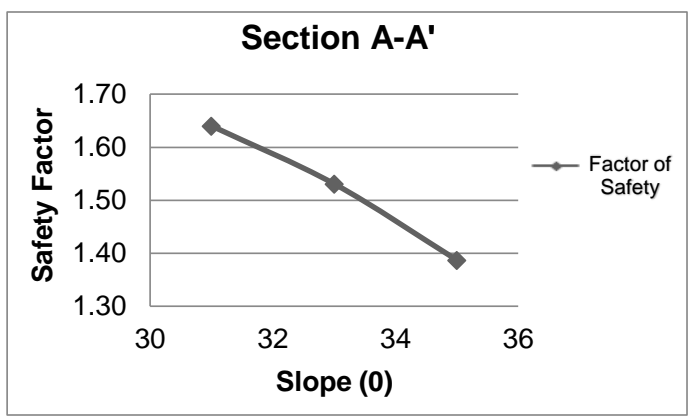

Figure 4. Graph of effect of slope against safety factors

From the results of the analysis of the safety factors carried out on the eight sections of Pit 22 GN PT Kitadin Site Embalut. The value of safety factors and slope landslide probabilities are grouped according to Keputusan Menteri ESDM No 1827 K/30/MEM/2018 (Table 6) (Menteri Energi dan Sumber Daya Mineral, 2018).

Table 6. Grouping of safety factor values

\begin{tabular}{cccc}
\hline $\begin{array}{c}\text { Sectio } \\
\mathrm{n}\end{array}$ & $\begin{array}{c}\text { Type of } \\
\text { Slope }\end{array}$ & FoS & Avalanche Pan \\
\hline A-A' $^{\prime}$ & & 1.231 & Low \\
B-B' & & 1.482 & High \\
C-C' & & 1.390 & Middle Class \\
D-D' & Overall & 1.318 & Middle Class \\
E-E' & Slope & 2.831 & High \\
F-F' & & 2.426 & High \\
G-G' & & 2.242 & High \\
H-H' & & 2.396 & High \\
\hline
\end{tabular}

Source: The research result
2. Differences in cohesion values and inner shear angles

Slope constituent material in the study area consisted of claystone and Ssandstone, each of which had different cohesion and shear angles. The strength of the slope material to resist landslides is very dependent on the binding force between the grains (cohesion) and the inner shear angle, which affects the size of the shear strength so that it will affect the size of the slope safety factor value. According to the Mohr-Coulomb shear strength equation the relationship can be expressed in the equation: $\mid=C+\int_{n}$ tan ). So the greater the value.

\section{CONCLUSIONS AND SUGGESTIONS}

\section{Conclusion}

Based on the results of research and discussion on the Analysis of Slope Stability of Highwall Pit 22 GN at PT Kitadin Site Embalut can be concluded as follows:

1. Results of direct shear strength testing that has been done on some sample materials so as to obtain the following characteristic values: Soil Material $\mathrm{C}=$ $80.47 \mathrm{KN} / \mathrm{m}^{2}$ and $\varnothing=21.09^{\circ}$, Soft Material $\mathrm{C}=2.00 \mathrm{KN} / \mathrm{m}^{2}$ and $\varnothing=8.90^{\circ}$, Material Disposal $\mathrm{C}=4.00 \mathrm{KN} / \mathrm{m}^{2}$ and $\varnothing=10.00^{\circ}$, Overburden $\mathrm{C}=132.39 \mathrm{KN} / \mathrm{m}^{2}$ and $\varnothing=$ $31.76^{\circ}$, Coal Seam $23 \mathrm{C}=138.56 \mathrm{KN} / \mathrm{m}^{2}$ and $\varnothing=38.94^{\circ}$, Interburden $23 \mathrm{C} 22 \mathrm{C}=$ $144.07 \mathrm{KN} / \mathrm{m}^{2}$ and $\varnothing=31.04^{\circ}$, Coal Seam $22 \mathrm{C}=138.56 \mathrm{KN} / \mathrm{m}^{2}$ and $\varnothing=35.94^{\circ}$, Interburden 22 C $20 \mathrm{C}=162.26 \mathrm{KN} / \mathrm{m}^{2}$ and $\varnothing=32.45^{\circ}$, Coal Seam $20 \mathrm{C}=115.33$ $\mathrm{KN} / \mathrm{m}^{2}$ and $\varnothing=36.78^{\circ}$, Interburden $20 \mathrm{C}$ $17 \mathrm{C}=259.66 \mathrm{KN} / \mathrm{m}^{2}$ and $\varnothing=34.60^{\circ}$, Coal Seam $17 \mathrm{C}=150.00 \mathrm{KN} / \mathrm{m}^{2}$ and $\varnothing=$ $40,00^{\circ}$, Interburden $17 \mathrm{C}$ 15UUU $\mathrm{C}=$ $458.64 \mathrm{KN} / \mathrm{m}^{2}$ and $\varnothing=35.09^{\circ}$, Under burden $\mathrm{C}=329.99 \mathrm{KN} / \mathrm{m}^{2}$ and $\varnothing=44.57^{\circ}$.

2. The slope of the Geometry Design results in Pit 22 GN with a width of berm $=2-5$ meters, width of berm road $=20$ meters, height of single slop $=5-18$ meters, single angle slope $=20-60$ degrees, overall height slope $=27-50$ meters and overall angle slope $=25-35$ degrees .

3. Results of analysis of slope stability (FK) highwall Pit 22 GN PT Kitadin Site Embalut carried out with eight sections, then obtained the value of safety factor, section $A-A^{\prime}=1.531$, section $B-B^{\prime}=1,482$, 
section $C-C^{\prime}=1,390$, section $D^{-} D^{\prime}=1,32$, section $E_{-} E^{\prime}=2,381$, section $F^{-} F^{\prime}=2,426$, section $\mathrm{G}-\mathrm{G}^{\prime}=2,242$ and section $\mathrm{H}-\mathrm{H}^{\prime}=$ 2,396 . From the results of the eight section simulation, the highwall safety factor of Pit 22 GN PT Kitadin Site Embalut $=1.896$.

\section{Suggestion}

In the pit $22 \mathrm{GN}$ area there are several materials which are disposal materials so that slope monitoring can be carried out periodically because the material characteristics are low so the potential for landslides and slope dimensions is adjusted to the value of material characteristics. While the original material needs to be adjusted to the dimensions of the slope so that the slope is more efficient.

\section{ACKNOWLEDGMENTS}

The authors would like gratefully acknowledge the Dean of the Engineering Faculty, Kutai Kartanegara University, Dr. Ibnu Hasyim, MT, PT Kitadin site Embalut and all parties that cannot be mentioned one by one for their assistance during this research.

\section{REFERENCE}

Azizi, M. A. and Handayani, H. E. (2011) 'Karakterisasi parameter masukan untuk analisis kestabilan lereng tunggal (Studi kasus di PT.Tambang Batubara Bukit AsamTbk', in Prosiding Seminar Nasional AVoER ke-3. Palembang: Universitas Sriwijaya, pp. 328-341.

Bishop, A. W. (1955) 'The use of the slip circle in the stability analysis of slopes', Géotechnique, 5(1), pp. 7-17. doi: 10.1680/geot.1955.5.1.7.

Budiman, M. (2011) Geologi dan studi kestabilan lereng daerah Dlinog dan sekitarnya Kecamatan Dlingo Kabupaten Bantul

\author{
Daerah Insitmewa Yogyakarta. \\ Universitas Pembangunan Nasional \\ 'Veteran' Yogyakarta.
}

Das, B. M., Endah, N. and Mochtar, I. B. (1993) Mekanika tanah (Prinsip-prinsip rekayasa geoteknis). 2nd edn. Jakarta: Erlangga.

Hardiyatmo, H. C. (2017) Analisis dan perancangan fondasi $I$. 3rd edn. Yogyakarta: Gadjah Mada University Press.

Hariyadi, S. (2014) Analisis stabilitas lereng timbunan pada PT Kayan Putra Utama Coal, Kabupaten Kutai Kartanegara, Provinsi Kalimantan Timur. Universitas Pembangunan Nasioanl 'Veteran' Yogyakarta.

Hoek, E. and Brown, E. T. (1980) 'Empirical strength criterion for rock masses', in Journal of the Power Division: Proceedings of American Society of Civil Engineers Vol. 106. American Society of Civil Engineering, pp. 1013-1035.

Karyono (2004) 'Kemantapan lereng batuan: Langkah perhitungan faktor keamanan untuk longsoran busur dengan menggunakan diagram Hoek'. Bandung: Universitas Islam Bandung, p. 19. Available at: https://www.academia.edu/4384577/Ke mantapan_Lereng_Batuan_Ir._Karyono M.T. KEMANTAPAN_LERENG_BATU ANLangkah_Perhitungan_Faktor_Keam anan_Untuk_Longsoran_Busur_Dengan _Menggunakan_Diagram_Hoek.

Menteri Energi dan Sumber Daya Mineral (2018) Keputusan Menteri Energi dan Sumber daya Mineral No. 1827 K/30/MEM/2018 Tentang pedoman pelaksanaan kaidah teknik pertambangan yang baik. Indonesia.

Zakaria, Z. (2010) 'Model starlet, suatu usulan untuk mitigasi bencana longsor dengan pendekatan genetika wilayah (Studi kasus: Longsoran Citatah, Padalarang, Jawa)', Indonesian Journal on Geoscience, 5(2), pp. 93-112. doi: 10.17014/ijog.v5i2.95. 